\section{Variation in the energy and nutrient supply of horses under practical conditions}

\author{
Heike Sliwinski ${ }^{1}$, Ewald Rosenberger ${ }^{2}$ and Frieder J. Schwarz ${ }^{1}$ \\ Department of Animal Science, Division of Animal Nutrition, Technical Uni- \\ versity of Munich, Freising-Weihenstephan' and Bavarian State Research \\ Center for Agriculture, Institute of Animal Breeding, Poing ${ }^{2}$
}

\section{Introduction}

Ration formulation for the correct supply of energy and nutrients to meet performance is uncommon for horses, they are usually fed in a 'traditional' and very 'subjective' way. This study is a survey of the present status of energy and nutrient supply to horses in Bavaria, combining analyses of the feeds used with calculation of energy, crude protein and mineral supply of the whole rations.

\section{Material and methods}

Forty farm/stables in Bavaria where horses (mainly riding horses, German Warmblood) are kept were visited for sampling. The horses were used as leisure horses or for competitions. The individual ration components of a selected horse were weighed. The quantity and composition of the mineral supplement was also recorded. The horses' live weight was estimated according to the equation given by Carrol and Huntington (1988), where LW $(\mathrm{kg})=$ (girth, $\mathrm{cm}) 2 \mathrm{x}$ body length, $\mathrm{cm} / 1$ 1900. Age and energy expenditure (light, medium or heavy work) were noted. The actual supply of energy, crude protein and minerals was calculated from the weight of the individual component in the ration and the chemical analyses (Schwarz et al. 2005) of the feeds used, and these results were compared with the recommendations for rations which would meet their requirements (GFE, 1994).

\section{Results}

The average estimated live weight was $633 \mathrm{~kg}$, and 23 of the horses were considered to be in light work (performance category 1, PC 1), the other 17 in medium/heavy work (performance category 2, PC2). Horses in PC1 were offered an average of $10.7 \mathrm{~kg} \mathrm{DM} / \mathrm{d}$ (range 5.9 - 15.2), while those in PC2 received between 7.7 and $13.8 \mathrm{~kg} \mathrm{DM} / \mathrm{d}$ (average 11.5). Table 1 shows the mean supply of energy, crude protein, calcium, phosphorus, magnesium and sodium, with the range given in brackets, while that of trace elements (copper, zinc manganese and selenium, figures in $\mathrm{mg} / \mathrm{kg}$ and $\mu \mathrm{g} / \mathrm{kg}$ whole ration DM) is shown in Table 2 .

\section{Discussion}

It is important to stress that the data were obtained from only a few random samples of one horse's ration on one day per
Table 1 Average daily intake of digestible energy, digestible crude protein and major elements (range in brackets), data per horse per day.

\begin{tabular}{|l|c|c|}
\hline & \multicolumn{2}{|c|}{ Performance category } \\
\hline & maintenance/light work & medium/heavy work \\
\hline Digestible energy (MJ DE) & $89.9(54-163)$ & $120.6(72-153)$ \\
\hline Digestible protein (g) & $563(240-1014)$ & $735(345-1028)$ \\
\hline $\mathrm{Ca}(\mathrm{g})$ & $51.7(25-81)$ & $66.4(25-125)$ \\
\hline $\mathrm{P}(\mathrm{g})$ & $28.5(17-48)$ & $33.3(16-46)$ \\
\hline $\mathrm{Mg}(\mathrm{g})$ & $17.9(9-27)$ & $22.2(15-33)$ \\
\hline $\mathrm{Na}(\mathrm{g})$ & $9.7(2-24)$ & $11.8(6-32)$ \\
\hline
\end{tabular}

Table 2 Mean concentration and range of trace elements in the whole rations (including mineral supplementation).

\begin{tabular}{|c|c|c|c|}
\hline $\begin{array}{c}\mathrm{Cu} \\
(\mathrm{mg} / \mathrm{kg} \mathrm{DM})\end{array}$ & $\begin{array}{c}\mathrm{Zn} \\
(\mathrm{mg} / \mathrm{kg} \mathrm{DM})\end{array}$ & $\begin{array}{c}\mathrm{Mn} \\
(\mathrm{mg} / \mathrm{kg} \mathrm{DM})\end{array}$ & $\begin{array}{c}\mathrm{Se} \\
(\mu \mathrm{gg} / \mathrm{kg} \mathrm{DM})\end{array}$ \\
\hline $\begin{array}{c}9.22 \\
(4.1-17.0)\end{array}$ & $\begin{array}{c}55.0 \\
(22.3-91.7)\end{array}$ & $\begin{array}{c}99.7 \\
(33.9-242.8)\end{array}$ & $\begin{array}{c}126.7 \\
(16-378)\end{array}$ \\
\hline
\end{tabular}

farm/stables. Also, the nutrient supply of the total ration is given with no weights or samples of refusals taken. The results show a generally satisfactory level of supply across all rations and nutrients, but with considerable deviations leading to both under- and over-supply situations.

In fifteen of the forty cases the energy supply exceeded recommendations by $25 \%$ or more. This is probably due to the low performance demands on the leisure horses. On the other hand, four horses received clearly much less energy than required ( $<75 \%$ of recommended value). While there were particularly many cases of over-supply of crude protein, all rations were within tolerance margins (Meyer and Coenen, 2002). The supply of minerals did not, in general, cover the requirements, showing a significant deficiency especially in sodium if only supplied by rations given in practical conditions (forage, concentrates and mineral supplement). Additions of salt (possibly via salt lick) for sodium are required, but salt licks were not considered when the data were collected. A frequent imbalance in the Ca:P ratio was detected. Extreme over- and under-supply situations were found for trace elements, especially for $\mathrm{Cu}$ and $\mathrm{Se}$. The results underline the importance of regular control and examinations of the ration components, together with the need for accurate calculations of whole rations.

\section{References}

Carrol C. and Huntington P. (1988): Body conditioning scoring and weight estimates of horses. Equine vet. J. 20, 21-45

GFE (1994): Ausschuß für Bedarfsnormen der Gesellschaft für Ernährungsphysiologie. Empfehlungen zur Energie- und Nährstoffversorgung der Pferde, DLG-Verlag Frankfurt

Meyer H. and Coenen M. (2002): Pferdefütterung, 4. Aufl. Parey-Verlag Berlin

Schwarz F. J., Sliwinski H., Schuster M. and Rosenberger E. (2005): Variation in the nutrient composition of different feedstuffs for horses. Equine Nutr. Conf. Hannover.

\section{F. J. Schwarz}

Department of Animal Science, Division of Animal Nutrition

Technical University of Munich

85350 Freising-Weihenstephan

schwarzf@wzw.tum.de 